\title{
Stefan Heinrich: Covenants als Alternative zum institutionellen Gläubigerschutz, Eine rechtsvergleichende und ökonomische Analyse; Schriften zum Wirtschaftsrecht, Band 228
}

\section{Duncker \& Humblot, Berlin, 2009}

\section{Juergen G. Backhaus}

Published online: 21 January 2012

(C) Springer Science+Business Media, LLC 2012

Covenants are complex contracts which take the place of bail or other forms of securing credit. Instead, they subject the debtor to a strict regimen and endow the credit for with extensive control rights. Traditionally, creditors were protected by legislation and regulation. Now that there is a wide choice of legal forms all across the European spectrum the anglo-american covenant has also found its place in Germany. Can it replace the traditional protective structures? Heinrich's conclusion is that covenants provide a clear improvement over the ineffective rules and regulations.

Heinrich pleads for an unequivocal reliance on covenants not just in order to protect creditors but also to improve corporate governance through enhanced transparency. At the same time for the protection of debtors he suggest civil judicial review of the covenants.

J. G. Backhaus ( $\square)$

Krupp Chair in Public Finance and Fiscal Sociology, University of Erfurt, Nordhäuser Strasse 63, 99089 Erfurt, Germany

e-mail: juergen.backhaus@uni-erfurt.de 